\title{
Scleroderma and Pulmonary Hypertension ${ }^{(*)}$
}

\section{Esclerodermia e Hipertensão Pulmonar}

\author{
Karen A. Fagan, MD(1), David H. Collier, $\mathrm{MD}^{(2)}$ e David B. Badesch, MD ${ }^{(3)}$
}

\begin{abstract}
Patients with scleroderma are at increased risk for the development of pulmonary hypertension, and the development of unexplained dyspnea or an isolated decrease in diffusing capacity should prompt evaluation. Echocardiography is often helpful in this situation, with further testing being performed as indicated. Because the prognosis of untreated pulmonary hypertension occurring in the setting of scleroderma is generally quite poor, vigilance is required on the part of physicians following this "at risk" group of patients. The past decade has seen important advances in the treatment of pulmonary arterial hypertension, including intravenous epoprostenol, oral bosentan and subcutaneously infused treprostinil. As new therapies are developed for the treatment of pulmonary arterial hypertension, it is essential that patients with scleroderma-related disease are included in clinical trials.
\end{abstract}

Keywords: scleroderma, pulmonary hypertension, dyspnea.

\section{INTRODUCTION}

Pulmonary arterial hypertension is a life-threatening complication of several connective tissue diseases including scleroderma (both limited and diffuse), systemic lupus erythematosus (SLE), mixed connective tissue disease (MCTD) and less commonly rheumatoid arthritis (RA) and dermatomyositis/polymyositis (Table 1 ). This review will discuss the clinical presentation and treatment options for patients with pulmonary hypertension and the scleroderma spectrum of diseases.

\section{RESUMO}

Pacientes com esclerodermia têm risco aumentado para desenvolver hipertensão pulmonar. O aparecimento de dispnéia e/ou a diminuição da capacidade de difusão devem levar à suspeita imediata dessa complicação. A ecodopplercardiografia é importante para o diagnóstico e o seguimento desses casos. Os casos não tratados de hipertensão pulmonar em esclerodermia têm mau prognóstico, daí a necessidade em manter sob vigilância estes pacientes. Na última década surgiram avanços para o tratamento da hipertensão arterial pulmonar, incluindo os medicamentos epoprostenol EV, bosentan VO e treprostinil SC. À medida que novas terapias vão sendo desenvolvidas, torna-se necessário a realização de estudos clínicos de maior validade.

Palavras-chave: esclerodermia, hipertensão pulmonar, dispnéia.
TABLE 1

CONNECTIVE TISSUE DISEASES ASSOCIATED WITH PULMONARY ARTERIAL HYPERTENSION

Scleroderma
Diffuse
Limited
CRES

Systemic lupus erythematosus

Mixed connective tissue disease

Rheumatoid arthritis

Polymyositis/dermatomyositis

\footnotetext{
* Pulmonary Hypertension Center. Division of Pulmonary Sciences and Critical Care Medicine. University of Colorado Health Sciences Center. Recebido em 29/08/03. Aprovado, após revisão, em 20/10/03.

1. Assistant Professor of Medicine. Division of Pulmonary Sciences and Critical Care Medicine, Pulmonary Hypertension Center, University of Colorado Health Sciences Center.

2. Associate Professor of Medicine. Division of Rheumatology, University of Colorado Health Sciences Center.

3. Professor of Medicine. Clinical Director, Division of Pulmonary Sciences and Critical Care Medicine, Pulmonary Hypertension Center, University of Colorado Health Sciences Center.

Correspondence to: David B. Badesch, Clinical Director. Pulmonary Hypertension Center. Division of Pulmonary Sciences and Critical Care Medicine. University of Colorado Health Sciences Center. Box C-272 4200 E. Ninth Ave. Denver-CO 80111 , USA; e-mail: david.badesch@uchsc.edu
} 


\section{EPIDEMIOLOGY}

Pulmonary hypertension may complicate several of the connective tissue diseases (Table 1). Scleroderma is a progressive, multisystemic disease manifested by connective tissue and vascular lesions in many organs, including lung, kidney and $\operatorname{skin}^{(1-6)}$. Pulmonary manifestations include interstitial fibrosis, pulmonary arterial hypertension, constriction of the chest wall due to skin thickening, diaphragmatic dysfunction and chronic aspiration due to esophageal dysmotility $^{(7)}$. Pulmonary complications are the most frequent cause of death in patients with scleroderma ${ }^{(7,8)}$, and pulmonary vascular disease has a particularly adverse effect on the prognosis ${ }^{(9)}$.

The incidence of pulmonary hypertension varies between $6 \%-60 \%$ of patients with scleroderma ${ }^{(10,11)}$. Up to $33 \%$ of patients with diffuse scleroderma have pulmonary hypertension, both isolated and in association with interstitial lung disease ${ }^{(10,12-16)}$. In patients with limited scleroderma, formerly referred to as CREST (calcinosis cutis, Raynaud's phenomenon, esophageal dysmotility, sclerodactyly and telangiectasias), up to $60 \%$ of the patients have pulmonary hypertension ${ }^{(11,12,14,15,17)}$. While not all patients have clinically significant pulmonary hypertension, two thirds of the patients with scleroderma will have pathologic evidence of pulmonary vascular disease ${ }^{(17,18)}$. Stupai reported 2-year survival in patients with CREST without pulmonary hypertension to be greater than $80 \%$, while patients with pulmonary hypertension had a 2 -year survival of $40 \%{ }^{(11)}$. Sacks reported an overall survival of patients with pulmonary hypertension and either diffuse or limited scleroderma of approximately $50 \%$ during a 2 -year observational period following diagnosis ${ }^{(13)}$. Koh reported $40 \%$ survival at 2 years in patients with scleroderma and pulmonary hypertension, compared to better survival in scleroderma patients without organ failure or with other lung involvement (i.e. interstitial lung disease) ${ }^{(9)}$.

Pulmonary hypertension has been reported in 4\%-14\% of the patients with systemic lupus erythematosus (SLE) with an overall mortality rate of $25 \%-50 \%$ at two years from diagnosis of pulmonary hypertension ${ }^{(19-25)}$. Patients with mixed connective tissue disease (MCTD) have features of several connective tissue diseases including SLE, scleroderma, rheumatoid arthritis and polymyositis ${ }^{(26,27)}$. Most MCTD patients are either predominantly SLE or scleroderma with a myositis overlap. The behavior of the disease therefore follows either a predominantly SLE or scleroderma pattern. The incidence of pulmonary hypertension in patients with MCTD is not certain but one report found two thirds of patients with MCTD had evidence of pulmonary hypertension ${ }^{(28)}$ and pulmonary hypertension has been frequently cited cause of death in patients with MCTD ${ }^{(28-31)}$. This high incidence of pulmonary hypertension in MCTD is probably due to the predominant scleroderma pattern of this disease in many patients with MCTD.

Rheumatoid arthritis (RA) affects $5 \%$ of the population over 65 years old and pulmonary complications include interstitial pulmonary fibrosis, rheumatoid nodules and pleural effusions. The incidence of isolated pulmonary hypertension is unknown. In a recent report, $21 \%$ of the patients with RA without evidence of other pulmonary or cardiac disease had mild pulmonary hypertension ${ }^{(32)}$. The prognosis is not known. Other connective tissue diseases including dermatomyositis/polymyositis have been associated with pulmonary arterial hypertension but the incidence and prognosis are not known ${ }^{(33)}$.

\section{PATHOGENESIS}

The etiology of pulmonary hypertension in the scleroderma spectrum of diseases remains unknown. There appears to be direct involvement of the pulmonary circulation with intimal proliferation and medial hypertrophy, somewhat similar to that seen in primary pulmonary hypertension $^{(11,15,17,18,34,35)}$. Some cases may also be related to severe pulmonary parenchymal disease such as interstitial disease with hypoxemia. Additionally, diastolic dysfunction of the right and left ventricles has been seen in patients with scleroderma and may lead to pulmonary hypertension ${ }^{(36-38)}$.

Autoimmune processes have been implicated in the pathogenesis of pulmonary hypertension although the mechanism is not known. Positive anti-nuclear antibodies (ANA) are frequently found in pulmonary hypertension patients without a diagnosis of connective tissue disease, and pulmonary hypertension can occur before the onset of an identifiable connective tissue disease ${ }^{(39)}$. In patients with scleroderma, anti-centromere and anti-histone antibodies have been associated with vascular disease ${ }^{(40)}$. Anti-centromere antibodies are primarily seen in the limited form of systemic sclerosis. Since patients with the limited form of systemic sclerosis have a higher incidence of pulmonary hypertension than patients with diffuse disease, it is not surprising that anti-centromere antibodies be associated with a higher incidence of pulmonary 
hypertension. Anti-fibrillarin antibodies (anti-U3-RNP) are frequently found in patients with scleroderma and are more common with diffuse scleroderma associated pulmonary hypertension ${ }^{(41)}$. Antiendothelial antibodies (aECA) are present in $40 \%$ and $13 \%$ of the patients with diffuse scleroderma and CREST respectively and are associated with a higher incidence of pulmonary hypertension and digital infarcts ${ }^{(42)}$. Anti-fibrillarin antibodies and aECAs are also associated with pulmonary hypertension in $\mathrm{SLE}^{(43,44)}$. In patients with scleroderma and pulmonary hypertension, especially when accompanied by HLA-B35 antigen, anti-topoisomerase II-alpha antibodies are more common as are antibodies to fibrin bound tissue type plasminogen activator (tPA $)^{(45-47)}$.

Raynaud's phenomenon, vasospasm of the arterioles in the distal systemic circulation, is commonly reported in patients with scleroderma. In one report, all patients with pulmonary hypertension and CREST had Raynaud's, while $68 \%$ without pulmonary hypertension had this clinical manifestation ${ }^{(11)}$. Raynaud's is also common in patients with SLE and MCTD and pulmonary hyperten$\operatorname{sion}^{(21,43,48)}$, but only $10 \%-14 \%$ of the patients with primary pulmonary hypertension have Raynaud's phenomenon ${ }^{(49)}$. This observation has led to the "pulmonary Raynaud's" hypothesis that vasospasm contributes to the development of pulmonary hypertension ${ }^{(50,51)}$. Acute hypoxic pulmonary vasoconstriction may be more pronounced in patients with pulmonary hypertension and scleroderma than in patients with primary pulmonary hypertension ${ }^{(52)}$. However, another report found that pulmonary vasospasm was not present in patients with Raynaud's and scleroderma without pulmonary hypertension $^{(53)}$. Supporting this hypothesis, endothelial dysfunction may be important in the development of pulmonary hypertension ${ }^{(54,55)}$. Patients with scleroderma have defective endothelial-dependent vasodilatation ${ }^{(29)}$ and this may be related to decreased endothelial nitric oxide synthase $(\mathrm{eNOS})^{(56)}$. Decreased lung eNOS has been reported in severe primary pulmonary hypertension ${ }^{(57,58)}$. While the level of eNOS in connective tissue disease is not known, decreased production of lung NO has been found in patients with scleroderma and pulmonary hyperten$\operatorname{sion}^{(59,60)}$. Similarly, the expression of prostacyclin synthase in pulmonary endothelium may be decreased in patients with severe connective tissue disease associated with pulmonary hypertension ${ }^{(61)}$.

Endothelin-1 is increased in serum of patients with both diffuse and limited scleroderma ${ }^{(62,63)}$, and while endothelin levels correlate with survival in patients with scleroder$\mathrm{ma}^{(64)}$, they were not higher in those patients with pulmonary hypertension ${ }^{(62)}$. In contrast, higher serum endothelin levels are found in patients with SLE associated pulmonary hypertension than non-pulmonary hypertensive SLE patients ${ }^{(23)}$. The potential role of ET-1 in pulmonary hypertension has led to the use of endothelin antagonists in the treatment of patients with connective tissue disease associated pulmonary hypertension ${ }^{(65,66)}$. Serotonin may also play a role in the pathogenesis of pulmonary hypertension. In patients with systemic sclerosis and Raynaud's phenomenon, platelet serotonin concentrations are decreased and serum levels are increased ${ }^{(67,68)}$.

\section{CLINICAL PRESENTATION AND EVALUATION}

Dyspnea is the most common symptom of scleroderma presenting pulmonary hypertension. The clinical evaluation is similar to that of patients with primary pulmonary hypertension. History and physical examination often reveal findings of the underlying connective tissue disease (i.e. Raynaud's phenomenon, telangiectasias, rash, synovitis, interstitial lung disease, etc.). Decreased diffusing capacity of the lung is the most common pulmonary function abnormality and should prompt an evaluation for both pulmonary vascular and interstitial lung disease ${ }^{(69)}$. A diffusing capacity lower than $40 \%$ of that predicted for lung volume places the patient in a poor prognostic category. Echocardiography may be helpful in the evaluation of patients suspected of having pulmonary hypertension as suggested by unexplained dyspnea or an isolated reduction in diffusing capacity. As previously discussed, patients with scleroderma should be considered an "at risk" group for the development of pulmonary hypertension, and echocardiography may reveal right ventricular hypertrophy and dilatation even before the onset of symptoms ${ }^{(70,71)}$. Ultimately, as with primary pulmonary hypertension, right heart catheterization is needed to confirm the diagnosis, assess hemodynamic severity and exclude other possible contributing factors such as an occult congenital heart defect. While it is generally thought that patients with scleroderma associated pulmonary hypertension are less likely to demonstrate a favorable response to vasodilator therapy than patients with primary pulmonary hypertension (in whom the response rate is approximately $20 \%-25 \%$ ), a hemodynamically monitored assessment of vasoreactivity is still advocated by some experts. 


\section{THERAPY}

Several therapeutic options are available for the treatment of scleroderma associated pulmonary hypertension (Table 2). Oral vasodilators (calcium channel antagonists, angiotensin converting enzyme inhibitors and alpha-adrenergic antagonists) have been used to treat pulmonary hypertension in patients with scleroderma. Although it has been reported that calcium channel blockers have improved survival in some patients with scleroderma associated pulmonary hypertension ${ }^{(1-6)}$, it is generally acknowledged that only a small percentage of such patients respond favorably to these agents. Angiotensin converting enzyme inhibitors and alpha-adrenergic blocker (prazosin) have also been used both acutely and in the long term on the treatment of connective tissue disease associated pulmonary hypertension ${ }^{(2,72,73)}$.

TABLE 2

POTENTIAL THERAPEUTIC OPTIONS FOR SCLERODERMA PULMONARY HYPERTENSION

\section{Vasodilators}

Calcium channel blockers

Angiotensin converting enzyme inhibitors

Alpha-adrenergic blockers

Prostaglandin preparations

IV epoprostenol

SC treprostinil

Inhaled iloprost

Inhaled Nitric 0xide

\section{Endothelin antagonists}

Bosentan

Serotonin antagonists

Ketanserin

Sarpogrelate

\section{Immunosuppressive therapy}

Corticosteroids

Cyclophosphamide

Bone marrow transplantation

Lung/Heart Lung transplantation

In a randomized, multicentric study of continuously intravenously infused epoprostenol, improvement was seen in patients with pulmonary hypertension due to scleroderma ${ }^{(74)} .111$ patients with pulmonary hypertension and the scleroderma spectrum of disease $(70 \%$ with limited disease, $13 \%$ with diffuse disease, $11 \%-14 \%$ with overlap syndrome, and $5 \%$ with features of scleroderma) were randomized to receive continuous infusion of epoprostenol vs. conventional treatment for 12 weeks. Epoprostenol improved exercise capacity, cardiopulmonary hemodynamics, New York Heart Association functional class, Borg dyspnea scale and likely Raynaud's phenomenon. However, there was no mortality benefit as has been seen in the same treatment duration with primary pulmonary hypertension ${ }^{(75)}$, possibly due to the multisystemic nature of this disease ${ }^{(74)}$. It is important to point out that the study was not powered to detect a survival difference. Others have also found both short and longterm improvement with epoprostenol ${ }^{(9,76-78)}$. Long-term follow-up of the patients in our study has suggested that epoprostenol may improve survival compared to historical controls. However, in general it appears as though survival/prognosis is worse for scleroderma associated pulmonary hypertension as compared to patients with primary pulmonary hypertension. Treatment with epoprostenol in some patients has been associated with reports of pulmonary edema possibly due to the presence of pulmonary veno-occlusive disease or pulmonary capillary hemangiomatosis ${ }^{(79-82)}$. As it is very rare, pulmonary veno-occlusive disease may be more common in patients with connective tissue disease ${ }^{(83)}$.

Increasing evidence has suggested the importance of endothelin-1 in the pathogenesis of pulmonary hypertension. In a multicentric, randomized, double-blinded placebo controlled trial of endothelin receptor blocker bosentan (Tracleer $\left.{ }^{\circledR}\right)$ for the treatment of pulmonary arterial hypertension, 213 patients with pulmonary hypertension, either primary or due to connective tissue disease (scleroderma and lupus), were randomized to receive placebo or bosentan at $125 \mathrm{mg}$ or $250 \mathrm{mg}$ orally twice daily ${ }^{(66)}$. After 16 weeks, distance walked in six minutes, functional class, Borg dyspnea index and time to clinical worsening improved in patients receiving bosentan. In contrast to the improvement in patients with primary pulmonary hypertension, bosentan prevented the deterioration in six-minute walking compared to placebo, suggesting that patients with scleroderma did less well overall. Nevertheless, relative stability may represent a favorable outcome in a disease with an otherwise very poor prognosis. Bosentan has been associated with a dose-dependent incidence of increased liver function tests, and monthly follow-up of these tests is required by the United States Food and Drug 
Administration. Other potential side effects are thought to include mild anemia, fluid retention, teratogenicity, and possibly testicular dysfunction and male infertility. Even in the light of these potential adverse effects, the development of this oral therapy is thought to represent a significant advance.

Various prostacyclin analogues and delivery systems have been studied recently. Inhaled iloprost, a stable analogue of epoprostenol, was tested in 5 patients with limited CREST and severe pulmonary hypertension. After one year, quality of life, functional class and hemodynamics improved, and this improvement was maintained for 2 years in 3 of 5 patients ${ }^{(84)}$. Treprostinil, a stable prostacyclin analogue administered subcutaneously, was approved for use in patients with pulmonary arterial hypertension ${ }^{(85)}$. Beraprost sodium, an orally bioactive prostacyclin analogue, improved six-minute walking distance in patients with primary pulmonary hypertension but not in patients with connective tissue disease ${ }^{(86)}$.

Although NO has utility in acute pulmonary vasodilator testing in patients with scleroderma, there have not been any reports of long-term use of $\mathrm{NO}$ in the treatment of scleroderma associated pulmonary hypertension ${ }^{(87)}$. The selective serotonin receptor 2 antagonist ketanserin acutely improved pulmonary artery pressure and cardiac output in patients with scleroderma associated pulmonary hypertension $^{(88)}$, while sarpogrelate, another serotonin receptor 2 antagonist, administered orally for 12 months, decreased

\section{REFERENCES}

1. Alpert MA, Pressly TA, Mukerji V, et al: Acute and long-term effects of nifedipine on pulmonary and systemic hemodynamics in patients with pulmonary hypertension associated with diffuse systemic sclerosis, the CREST syndrome and mixed connective tissue disease. Am J Cardiol 1991;68(17):1687-91.

2. Glikson M, Pollack A, Dresner-Feigin R, Galun E, Rubinow A: Nifedipine and prazosin in the management of pulmonary hypertension in CREST syndrome. Chest 1990;98(3):759-61.

3. O’Brien JT, Hill JA, Pepine CJ: Sustained benefit of verapamil in pulmonary hypertension with progressive systemic sclerosis. Am Heart J 1985;109(2):380-2.

4. Rich S, Kaufmann E, Levy PS: The effect of high doses of calciumchannel blockers on survival in primary pulmonary hypertension. N Engl J Med 1992;327(2):76-81.

5. Sfikakis PP, Kyriakidis MK, Vergos CG, et al: Cardiopulmonary hemodynamics in systemic sclerosis and response to nifedipine and captopril. Am J Med 1991;90(5):541-6. mean pulmonary arterial pressure and increased right ventricular ejection fraction ${ }^{(89)}$. These reports suggest a role for serotonin in the pathogenesis of scleroderma associated pulmonary arterial hypertension although a randomized, controlled trial has not been done.

Corticosteroids with and without cyclophosphamide ${ }^{(25)}$, long-term plasma exchange ${ }^{(90)}$ and autologous stem cell transplantation $^{(91)}$ have been reported to improve or stabilize pulmonary hypertension in patients with scleroderma. However, these represent case reports or retrospective case studies and no prospective study of immunosuppressive therapy has been completed in patients with connective tissue disease related to pulmonary hypertension. Using immunosuppressive therapy may be more successful in patients with SLE than scleroderma.

Surgical treatment, including atrial septostomy ${ }^{(92)}$ and lung or heart-lung transplantation, may be considered for patients with severe pulmonary arterial hypertension in association with connective tissue disease. Survival in patients with connective tissue disease associated pulmonary hypertension who undergo lung or heart-lung transplantation was not different than in patients with primary pulmonary hypertension ${ }^{(93)}$. Lung transplant may also be beneficial to patients with severe fibrotic lung disease. Appropriate patient selection is important, though, and lung transplantation may be relatively contraindicated in patients with significant esophageal dysmotility or renal dysfunction.

6. Shinohara S, Murata I, Yamada H, et al: Combined effects of diltiazem and oxygen in pulmonary hypertension of mixed connective tissue disease. J Rheumatol 1994;21(9):1763-65.

7. Minai OA, Dweik RA, Arroliga AC: Manifestations of scleroderma pulmonary disease. Clin Chest Med 1998;19(4):713-31, viII-IX.

8. Arroliga AC, Podell DN, Matthay RA: Pulmonary manifestations of scleroderma. J Thorac Imaging 1992;7(2):30-45.

9. Koh ET, Lee P, Gladman DD, Abu-Shakra M: Pulmonary hypertension in systemic sclerosis: an analysis of 17 patients. Br J Rheumatol 1996;35(10):989-93.

10. Battle RW, Davitt MA, Cooper SM, et al: Prevalence of pulmonary hypertension in limited and diffuse scleroderma. Chest 1996;110(6): 1515-19.

11. Stupi AM, Steen VD, Owens GR, Barnes EL, Rodnan GP, Medsger Jr TA: Pulmonary hypertension in the CREST syndrome variant of systemic sclerosis. Arthritis Rheum 1986;29(4):515-24.

12. MacGregor AJ, Canavan R, Knight C, et al: Pulmonary hypertension in systemic sclerosis: risk factors for progression and consequences for survival. Rheumatology (Oxford) 2001;40(4):453-9. 
13. Sacks DG, Okano Y, Steen VD, Curtiss E, Shapiro LS, Medsger Jr TA.: Isolated pulmonary hypertension in systemic sclerosis with diffuse cutaneous involvement: association with serum anti-U3RNP antibody. J Rheumatol 23(4):639-42, 1996.

14. Thurm CA, Wigley FM, Dole WP, Wise RA: Failure of vasoldilator infusion to alter pulmonary diffusing capacity in systemic sclerosis. Am J Med 1991;90(5):547-52.

15. Ungerer RG, Tashkin DP, Furst D, et al; Prevalence and clinical correlates of pulmonary arterial hypertension in progressive systemic sclerosis. Am J Med 1983;75(1):65-74.

16. Van den Hoogen FH, Spronk PE, Boerbooms AM, et al: Longterm follow-up of 46 patients with anti-(U1)snRNP antibodies. Br J Rheumatol 1994;33(12):1117-20.

17. Salerni R, Rodnan GP, Leon DF, Shaver JÁ: Pulmonary hypertension in the CREST syndrome variant of progressive systemic sclerosis (scleroderma). Ann Intern Med 1977;86(4):394-9.

18. Young RH, Mark GJ: Pulmonary vascular changes in scleroderma. Am J Med 1978;64(6):998-1004.

19. Asherson RA, Higenbottam TW, Dinh Xuan AT, Khamashta MA, Hughes GR: Pulmonary hypertension in a lupus clinic: experience with twenty-four patients. J Rheumatol 1990;17(10):1292-98.

20. Badui E, Garcia-Rubi D, Robles E, et al: Cardiovascular manifestations in systemic lupus erythematosus. Prospective study of $100 \mathrm{pa}-$ tients. Angiology 1985;36(7):431-41.

21. Li EK, Tam LS: Pulmonary hypertension in systemic lupus erythematosus: clinical association and survival in 18 patients. J Rheumatol 1999;26(9):1923-29.

22. Orens JB, Martinez FJ, Lynch 3rd. JP: Pleuropulmonary manifestations of systemic lupus erythematosus. Rheum Dis Clin North Am 1994;20(1):159-93.

23. Shen JY, Chen SL, Wu YX, et al: Pulmonary hypertension in systemic lupus erythematosus. Rheumatol Int 1999;18(4):147-51.

24. Simonson JS, Schiller NB, Petri M, Hellmann DB: Pulmonary hypertension in systemic lupus erythematosus. J Rheumatol 1989;16(7):918-25.

25. Tanaka E, Harigai M, Tanaka M, Kawaguchi Y, Hara M, Kamatani $\mathrm{N}$ : Pulmonary hypertension in systemic lupus erythematosus: evaluation of clinical characteristics and response to immunosuppressive treatment. J Rheumatol 2002;29(2):282-7.

26. Prakash UB: Respiratory complications in mixed connective tissue disease. Clin Chest Med 1998;19(4):733-46, IX.

27. Sharp GC, Irvin WS, Tan EM, Gould RG, Holman HR: Mixed connective tissue disease-an apparently distinct rheumatic disease syndrome associated with a specific antibody to an extractable nuclear antigen (ENA). Am J Med 1972;52(2):148-59.

28. Sullivan WD, Hurst DJ, Harmon CE, et al: A prospective evaluation emphasizing pulmonary involvement in patients with mixed connective tissue disease. Medicine (Baltimore) 1984;63(2):92-107.

29. Burdt MA, Hoffman RW, Deutscher SL, Wang GS, Johnson JC, Sharp GC: Long-term outcome in mixed connective tissue disease: longitudinal clinical and serologic findings. Arthritis Rheum 1999;42(5):899-909.

30. Love PE, Santoro SA: Antiphospholipid antibodies: anticardiolipin and the lupus anticoagulant in systemic lupus erythematosus (SLE) and in non-SLE disorders. Prevalence and clinical significance. Ann Intern Med 1990;112(9):682-98.
31. Wiener-Kronish JP, Solinger AM, Warnock ML, Churg A, Ordonez N, Golden JÁ: Severe pulmonary involvement in mixed connective tissue disease. Am Rev Respir Dis 1981;124(4):499-503.

32. Dawson JK, Goodson NG, Graham DR, Lynch MP: Raised pulmonary artery pressures measured with Doppler echocardiography in rheumatoid arthritis patients. Rheumatology (Oxford) 2000;39(12):1320-25.

33. Denbow CE, Lie JT, Tancredi RG, Bunch TW: Cardiac involvement in polymyositis: a clinicopathologic study of 20 autopsied patients. Arthritis Rheum 1979;22(10):1088-92.

34. Germain BF, Espinoza LR, Bergen LL, Vagesh M, Vasey FB: Increased prevalence of DRw3 in the CREST syndrome. Arthritis Rheum 1981;24(6):857-9.

35. Yousem SA: The pulmonary pathologic manifestations of the CREST syndrome. Hum Pathol 1990;21(5):467-74.

36. Aguglia G, Sgreccia A, Bernardo ML, et al: Left ventricular diastolic function in systemic sclerosis. J Rheumatol 2001;28(7):1563-67.

37. Coghlan JG, Mukerjee D: The heart and pulmonary vasculature in scleroderma: clinical features and pathobiology. Curr Opin Rheumatol 2001;13(6):495-9.

38. Giunta A, Tirri E, Maione S, et al: Right ventricular diastolic abnormalities in systemic sclerosis. Relation to left ventricular involvement and pulmonary hypertension. Ann Rheum Dis 2000;59(2):94-8.

39. Gurubhagavatula I, Palevsky HI: Pulmonary hypertension in systemic autoimmune disease. Rheum Dis Clin North Am 1997; 23(2):365-94.

40. Martin L, Pauls JD, Ryan JP, Fritzler MJ: Identification of a subset of patients with scleroderma with severe pulmonary and vascular disease by the presence of autoantibodies to centromere and histone. Ann Rheum Dis 1993;52(11):780-4.

41. Tormey VJ, Bunn CC, Denton CP, Black CM: Anti-fibrillarin antibodies in systemic sclerosis. Rheumatology (Oxford) 2001;40(10):1157-62.

42. Negi VS, Tripathy NK, Misra R, Nityanand S: Antiendothelial cell antibodies in scleroderma correlate with severe digital ischemia and pulmonary arterial hypertension. J Rheumatol 1998;25(3):462-6.

43. Asherson RA, Oakley CM: Pulmonary hypertension and systemic lupus erythematosus. J Rheumatol 13(1):1-5, 1986.

44. Yoshio T, Masuyama J, Sumiya M, Minota S, Kano S. Antiendothelial cell antibodies and their relation to pulmonary hypertension in systemic lupus erythematosus. J Rheumatol 1994; 21(11):2058-63.

45. Grigolo B, Mazzetti I, Meliconi R, et al: Anti-topoisomerase II alpha autoantibodies in systemic sclerosis- association with pulmonary hypertension and HLA-B35. Clin Exp Immunol 2000; 121(3):539-43.

46. Fritzler MJ, Hart DA, Wilson D, et al: Antibodies to fibrin bound tissue type plasminogen activator in systemic sclerosis. J Rheumatol 1995;22(9):1688-93.

47. Morse JH, Barst RJ, Fotino M, et al: Primary pulmonary hypertension, tissue plasminogen activator antibodies, and HLADQ7. Am J Respir Crit Care Med 1997;155(1):274-8.

48. Ueda N, Mimura K, Maeda H, et al: Mixed connective tissue disease with fatal pulmonary hypertension and a review of literature. Virchows Arch A Pathol Anat Histopathol 1984;404(4):335-40. 
49. Rich S, Dantzker DR, Ayres SM, et al. 1987. Primary pulmonary hypertension. A national prospective study. Ann Intern Med 107(2):216-23.

50. Fahey PJ, Utell MJ, Condemi JJ, Green R, Hyde RW: Raynaud's phenomenon of the lung. Am J Med 1984;76(2):263-9.

51. Rozkovec A, Bernstein R, Asherson RA, Oakley CM: Vascular reactivity and pulmonary hypertension in systemic sclerosis. Arthritis Rheum 1983;26(8):1037-40.

52. Morgan JM, Griffiths M, Du Bois RM, Evans TW: Hypoxic pulmonary vasoconstriction in systemic sclerosis and primary pulmonary hypertension. Chest 1991;99(3):551-6.

53. Shuck JW, Oetgen WJ, Tesar JT: Pulmonary vascular response during Raynaud's phenomenon in progressive systemic sclerosis. Am J Med 1985;78(2):221-7.

54. Kahaleh B, Matucci-Cerinic M: Raynaud's phenomenon and scleroderma. Dysregulated neuroendothelial control of vascular tone. Arthritis Rheum 1995;38(1):1-4.

55. Wigley FM: Raynaud's phenomenon and other features of scleroderma, including pulmonary hypertension. Curr Opin Rheumatol 1996;8(6):561-8.

56. Romero LI, Zhang DN, Cooke JP, et al: Differential expression of nitric oxide by dermal microvascular endothelial cells from patients with scleroderma. Vasc Med 2000;5(3):147-58.

57. Giaid A, Saleh D: Reduced expression of endothelial nitric oxide synthase in the lungs of patients with pulmonary hypertension. N Engl J Med 1995;333(4):214-21.

58. Mason NA, Springall DR, Burke M, et al: High expression of endothelial nitric oxide synthase in plexiform lesions of pulmonary hypertension. J Pathol 1998;185(3):313-8.

59. Kharitonov SA, Cailes JB, Black CM, Du Bois RM, Barnes PJ: Decreased nitric oxide in the exhaled air of patients with systemic sclerosis with pulmonary hypertension. Thorax 1997; 52(12):1051-55.

60. Rolla G, Colagrande P, Scappaticci E, et al: Exhaled nitric oxide in systemic sclerosis: relationships with lung involvement and pulmonary hypertension. J Rheumatol 2000;27(7):1693-98.

61. Tuder RM, Cool CD, Geraci MW, et al: Prostacyclin synthase expression is decreased in lungs from patients with severe pulmonary hypertension. Am J Respir Crit Care Med 1999;159(6):1925-32.

62. Morelli S, Ferri C, Polettini E, et al: Plasma endothelin-1 levels, pulmonary hypertension, and lung fibrosis in patients with systemic sclerosis. Am J Med 1995;99(3):255-60.

63. Yamane K: Endothelin and collagen vascular disease: a review with special reference to Raynaud's phenomenon and systemic sclerosis. Intern Med 1994;33(10):579-82.

64. Galie NGF, Bacchi-Reggiani L, et al: Relation of endothelin-1 to survival in patients with primar y pulmonary hypertension. European Journal of Clinical Investigation 1996;26 Suppl 1:48.

65. Channick RN, Simonneau G, Sitbon O, et al: Effects of the dual endothelin-receptor antagonist bosentan in patients with pulmonary hypertension: a randomised placebo-controlled study. Lancet 2001;358(9288):1119-23.

66. Rubin LJ, Badesch DB, Barst RJ, et al: Bosentan therapy for pulmonary arterial hypertension. N Engl J Med 2002; 346(12):896-903.
67. Klimiuk PS, Grennan A, Weinkove C, Jayson MI: Platelet serotonin in systemic sclerosis. Ann Rheum Dis 1989;48(7):586-9.

68. Biondi ML, Marasini B, Bianchi E, Agostoni A: Plasma free and intraplatelet serotonin in patients with Raynaud's phenomenon. Int J Cardiol 1988;19(3):335-9.

69. Scheja A, Akesson A, Wollmer P, Wollheim FA: Early pulmonary disease in systemic sclerosis: a comparison between carbon monoxide transfer factor and static lung compliance. Ann Rheum Dis 1993;52(10):725-9.

70. Denton CP, Cailes JB, Phillips GD, Wells AU, Black CM, Bois RM: Comparison of Doppler echocardiography and right heart catheterization to assess pulmonary hypertension in systemic sclerosis. Br J Rheumatol 1997;36(2):239-43.

71. Grunig E, Janssen B, Mereles D, et al: Abnormal pulmonary artery pressure response in asymptomatic carriers of primary pulmonary hypertension gene. Circulation 2000;102(10):1145-50.

72. Alpert MA, Pressly TA, Mukerji V, Lambert CR, Mukerji B: Shortand long-term hemodynamic effects of captopril in patients with pulmonary hypertension and selected connective tissue disease. Chest 1992;102(5):1407-12.

73. Niarchos AP, Whitman HH, Goldstein JE, Laragh JH: Hemodynamic effects of captopril in pulmonary hypertension of collagen vascular disease. Am Heart J 1982;104(4 Pt 1):834-8.

74. Badesch DB, Tapson VF, McGoon MD, et al: Continuous intravenous epoprostenol for pulmonary hypertension due to the scleroderma spectrum of disease. A randomized, controlled trial. Ann Intern Med 2000;132(6):425-34.

75. Barst RJ, Rubin LJ, Long WA, et al: A comparison of continuous intravenous epoprostenol (prostacyclin) with conventional therapy for primary pulmonary hypertension. The Primary Pulmonary Hypertension Study Group. N Engl J Med 1996;334(5):296-302.

76. Humbert M, Sanchez O, Fartoukh M, Jagot JL, Sitbon O, Simonneau G: Treatment of severe pulmonary hypertension secondary to connective tissue diseases with continuous IV epoprostenol (prostacyclin). Chest 1998;114 Suppl 1:80-82.

77. Klings ES, Hill NS, Ieong MH, Simms RW, Korn JH, Farber HW: Systemic sclerosis-associated pulmonary hypertension: short- and long- term effects of epoprostenol (prostacyclin). Arthritis Rheum 1999;42(12):2638-45.

78. Menon N, McAlpine L, Peacock AJ, Madhok R: The acute effects of prostacyclin on pulmonary hemodynamics in patients with pulmonary hypertension secondary to systemic sclerosis. Arthritis Rheum 1998;41(3):466-9.

79. Farber HW, Graven KK, Kokolski G, Korn JH: Pulmonary edema during acute infusion of epoprostenol in a patient with pulmonary hypertension and limited scleroderma. J Rheumatol 1999; 26(5):1195-96.

80. Palmer SM, Robinson LJ, Wang A, Gossage JR, Bashore T, Tapson VF: Massive pulmonary edema and death after prostacyclin infusion in a patient with pulmonary veno-occlusive disease. Chest 1998;113(1):237-40.

81. Preston IR, Klinger JR, Houtchens J, Nelson D, Mehta S, Hill NS: Pulmonary edema caused by inhaled nitric oxide therapy in two patients with pulmonary hypertension associated with the CREST syndrome. Chest 2002;121(2):656-9. 
82. Resten A, Maitre S, Humbert M, et al: Pulmonary arterial hypertension: thin-section CT predictors of epoprostenol therapy failure. Radiology 2002;222(3):782-8.

83. Mandel J, Mark EJ, Hales CA: Pulmonary veno-occlusive disease. Am J Respir Crit Care Med 2000;162(5):1964-73.

84. Launay D, Hachulla E, Hatron PY, et al: Aerosolized iloprost in CREST syndrome related pulmonary hypertension. J Rheumatol $2001 ; 28(10): 2252-56$

85. Simonneau G, Barst RJ, Galie N, et al: Continuous subcutaneous infusion of treprostinil, a prostacyclin analogue, in patients with pulmonary arterial hypertension: a double- blind, randomized, placebo-controlled trial. Am J Respir Crit Care Med 2002; 165(6):800-4.

86. Galie N, Humbert M, Vachiery JL, et al: Effects of beraprost sodium, an oral prostacyclin analogue, in patients with pulmonary arterial hypertension: a randomized, double-blind, placebo-controlled trial. J Am Coll Cardiol 2002;39(9):1496-1502.

87. Williamson DJ, Hayward C, Rogers P, et al: Acute hemodynamic responses to inhaled nitric oxide in patients with limited scleroderma and isolated pulmonary hypertension. Circulation 1996;94(3):477-82.
88. Seibold JR, Molony RR, Turkevich D, Ruddy MC, Kostis JB: Acute hemodynamic effects of ketanserin in pulmonary hypertension secondary to systemic sclerosis. J Rheumatol 1987; 14(3):519-24.

89. Kato S, Kishiro I, Machida M, Fuse D, Yoshida T, Kaneko N: Suppressive effect of sarpogrelate hydrochloride on respiratory failure and right ventricular failure with pulmonary hypertension in patients with systemic sclerosis. J Int Med Res 2000;28(6):258-68.

90. Ferri C, Emdin M, Storino FA, et al: Isolated pulmonary hypertension in diffuse cutaneous systemic sclerosis successfully treated with long-term plasma exchange. Scand J Rheumatol 2000; 29(3):198-200.

91. Binks M, Passweg JR, Furst D, et al: Phase I/II trial of autologous stem cell transplantation in systemic sclerosis: procedure related mortality and impact on skin disease. Ann Rheum Dis 2001; 60(6):577-84.

92. Allcock RJ, O'Sullivan JJ, Corris PA: Palliation of systemic sclerosisassociated pulmonary hypertension by atrial septostomy. Arthritis Rheum 2001;44(7):1660-62.

93. Rosas V, Conte JV, Yang SC, et al: Lung transplantation and systemic sclerosis. Ann Transplant 2000;5(3):38-43. 